\title{
The Gentleman and the Rogue: The Collaboration Between Charles Darwin and Carl Vogt
}

\author{
MARTIN AMREIN and KÄRIN NICKELSEN \\ Department of the History and Philosophy of Science \\ University of Bern \\ Sidlerstrasse 5 \\ CH-3012 Bern \\ Switzerland \\ E-mail: kaerin.nickelsen@philo.unibe.ch; martinamrein@gmx.ch
}

\begin{abstract}
This paper investigates the relationship between the eminent 19th-century naturalists Charles Darwin and Carl Vogt. On two separate occasions, Vogt asked Darwin for permission to translate some of the latter's books into German, and in both cases Darwin refused. It has generally been assumed that Darwin turned down Vogt as a translator because of the latter's reputation as a radical libertine who was extremely outspoken in his defence of scientific materialism and atheism. However, this explanation does not fit the facts, since, on closer investigation, Darwin not only gave serious consideration to engaging Vogt as the German translator of two of his books, albeit ultimately rejecting him, but he also collaborated with Vogt on the French editions of his works. In this paper we argue that this was not because Darwin was unaware of Vogt's personality and blunt writing style; rather, Darwin seems to have decided that the benefits he would gain from their association would clearly outweigh the risk of offending some of his readers: in working with Vogt, who was not only a knowledgeable scientist but also an avowed adherent of Darwinism, Darwin could be assured of the scientific quality of the translation and of an edition that would not distort his central concepts - both of which were by no means matters of course in 19th-century translations of scientific works.
\end{abstract}

Keywords: Carl Vogt, Charles Darwin, Darwinism, Descent of Man, scientific translation, scientific materialism, Variation of Animals and Plants under Domestication

\section{Introduction}

It is hard to imagine two 19th-century naturalists more dissimilar than Charles Darwin (1809-1882) and Carl Vogt (1817-1895). As far as is 
known, Darwin always behaved like a perfect gentleman, taking pains not to upset the public: he hesitated for more than 20 years before publishing his ideas on the transmutation of species. By contrast, Vogt regarded it almost as a moral principle to inflame public feelings; in order to defend his liberal mindset, his views on scientific materialism and his staunch atheism, Vogt frequently used a language in his speeches and publications that disconcerted even his most hardened readers.

Yet, despite their differences, Darwin corresponded with Vogt for several years. ${ }^{1}$ On two separate occasions, Vogt asked Darwin for permission to translate some of his books into German. And on both these occasions Darwin turned Vogt down in favour of the not-so-wellknown German naturalist Julius Victor Carus (1823-1903). ${ }^{2}$ Historians have tended to assume that Vogt's reputation was the reason Darwin declined to use his services; in their widely read biography of Darwin, for example, Adrian Desmond and James Moore write that when Vogt asked Darwin if he could translate The Variation of Animals and Plants under Domestication (Variation) for the German market, "Darwin knew enough [about Vogt] to opt for Huxley's man Victor Carus [...]. Indeed, there was a real worry about Vogt's language."3 Darwin's rejection of Vogt as translator of The Descent of Man (Descent) was even more dramatically cast by the same authors: it was "to Darwin's horror," that the "fiery Vogt" approached him; they concluded that Darwin "could never let the Descent go to such a sneering cynic."4 In their recent edition of Darwin's Descent, the same authors connect Darwin's rejection of Vogt to his links to the then notorious Anthropological Society of London, which had published the English version of Vogt's major work, Vorlesungen über den Menschen (Lectures on Man); a "cautious" Darwin, so the authors maintain, did not want to be seen to be associated with a man connected with this society. ${ }^{5}$

${ }^{1}$ Some of the correspondence between Darwin and Vogt is included in the recently published Volume 15 of The Correspondence of Charles Darwin (CCD) of the Darwin Correspondence Project. See Burkhardt et al., 1985-2005. We wish to thank the editors for making this volume available to one of us (M.A.) before its official release.

2 Julius Victor Carus is not to be confused with the more renowned German anatomist Carl Gustav Carus (1789-1869), an early 19th-century Naturphilosoph.

3 Desmond and Moore, 1992, p. 543.

${ }^{4}$ Desmond and Moore, 1992, p. 573.

5 See Darwin, 2004, p. 711: “A cautious Darwin refused his [Vogt's] offer to translate Origin [a typo for Variation or Descent]. Vogt had long held that the human races had independent origins, and the racists at the Anthropological Society London translated his last major book, Lectures on Man." Vogt had no intention of translating Origin but had asked Darwin for permission to translate Variation and Descent. 
In this paper, we argue that Darwin's decision not to give permission to Vogt to translate these works was neither related to fears concerning the language Vogt would use nor because of Vogt's outspoken and provocative personality and any undesirable political connections; on the contrary, Darwin was deeply interested in working with Vogt, and, although he picked Carus to carry out the German translations, Darwin did, in fact, collaborate with Vogt on the French editions of his works. And this was not because Darwin was unaware of Vogt's reputation; Darwin knew very well that the first translations of The Origin of Species (Origin) into German and French had been badly done, with some of his most central concepts distorted. ${ }^{6}$ Thus, the advantage of having a competent and trustworthy translator - which Vogt had earlier shown himself to be - far outweighed the risk of Darwin having himself associated with a sharp-tongued political radical.

\section{A Notorious Libertine}

Carl Vogt was born on 5 July 1817 in Giessen, a long-established university town in Germany. He began studying medicine there but had to leave abruptly when his liberal activities reached the attention of the reactionary authorities. ${ }^{7} \mathrm{He}$ fled to Switzerland, and in 1839 finished his medical studies in Bern, whereupon he began working with the geologist and zoologist Louis Agassiz (1807-1873) in Neuchâtel. During the next few years, encouraged by Agassiz, Vogt worked at improving his knowledge of natural history. When, in 1846, Agassiz accepted a chair at Harvard University in the United States, he wanted to take Vogt with him; Vogt, however, declined the offer and moved instead to Paris, where he mingled with some of France's most renowned naturalists. There Vogt earned his living as a newspaper correspondent, writing articles on current topics in the natural sciences. At the same time, Vogt

${ }^{6}$ As, for example, Nicolaas Rupke's study of translations of Vestiges shows, this was no exception but rather the rule in translation work. Translations in the 19th century tended to reflect the point of view (and understanding) of the translator, even at the cost of distorting the author's original intentions. See Rupke, 2000. Notwithstanding these difficulties, the importance of scientific translations in the 18th and 19th centuries was considerable. See on this point, e.g., Kanz, 1997, in particular pp. 63-102.

${ }^{7}$ For information on Vogt's life and work see, for example, (beyond the entries in the Allgemeine Deutsche Biographie and DSB) the following works: Judel, 2004; Kockerbeck, 1999; Pont et al., 1998; Tort, 1996, Sanner, 1994; Bernbeck, 1977; Gregory, 1977 (Chapter III); Bröker, 1972. Vogt's autobiography was published as C. Vogt, 1896a; it was complemented by an account of Vogt's son William, see W. Vogt, $1896 \mathrm{~b}$. 
also published independent zoological works, including, in 1845-1847, his widely read Physiologische Briefe (Physiological Letters), which brought him fame outside the zoological world. Herein Vogt revealed himself to be an outspoken supporter of physiological materialism, as, for example, in the following passage:

Every naturalist who thinks with any degree of consistency at all will, I think, come to the view that all those [human] faculties that we understand by the term psychic activities [Seelentätigkeiten] are but functions of the brain matter; or, to express myself a bit crudely here, that thoughts stand in the same relation to the brain as gall does to the liver or urine to the kidneys. To assume a soul that uses the brain as an instrument with which it can work as it pleases is pure nonsense. $^{8}$

Needless to say, Vogt's blunt words created quite a stir among scientists, philosophers and the devout; after the publication of Physiologische Briefe, Carl Vogt's notoriety was assured.

In 1847, Vogt returned to Giessen, having been appointed the town's first Professor of Zoology. This second stay in Germany coincided with a turbulent political period, during which democratic revolutionists were rebelling against the monarchical authorities throughout the German states. Thanks to his eloquence and fervent commitment to democracy, Vogt became a spokesman of the revolution, and when the democrats set up their parliaments, he was elected a left-wing representative. He campaigned tirelessly for: democracy; freedom of the press and assembly; a joint empire of all the German states; secularisation; and the freedom to combat the influence of the clergy. The democratic successes were not sustained, however, and after the Prussian militaries suspended the parliaments in Frankfurt and Stuttgart in 1849, Vogt was persecuted for his statements against the monarchy. After just 2 years in Germany he was forced to leave again, and for a second time Vogt was offered sanctuary by Switzerland.

${ }^{8}$ The English translation is a revised version of Gregory, 1977, p. 64. The original wording in Vogt, 1845-1847, p. 205: „Ein jeder Naturforscher wird wohl, denke ich, bei einigermassen folgerechtem Denken auf die Ansicht kommen, dass alle jene Fähigkeiten, die wir unter dam Namen der Seelentätigkeiten begreifen, nur Funktionen der Gehirnsubstanz sind; oder, um mich einigermassen grob hier auszudrücken, dass die Gedanken in demselben Verhältnisse etwa zu dem Gehirne stehen, wie die Galle zur Leber oder der Urin zu den Nieren. Eine Seele anzunehmen, die sich des Gehirnes wie eines Instrumentes bedient, mit dem sie arbeiten kann, wie es ihr gefällt, ist reiner Unsinn." 
The revolution having failed, Vogt turned his attention back to scientific questions, completing the work he had begun in Giessen. $\mathrm{He}$ also tried his hand at translating scientific works: in 1851, he released a German translation of the anonymously published Vestiges of the Natural History of Creation (Vestiges). ${ }^{9}$ In 1852, Vogt moved to the French-speaking part of Switzerland to take up the appointment of Professor of Geology (and later also of Zoology) at the Geneva Academy; in 1873, when the Academy gained university status, he was elected its first president.

During this period, Vogt began writing scientific and philosophical books intended for a general audience. In all his works Vogt remained a strict exponent of materialism. His Köhlerglaube und Wissenschaft (Blind Faith and Science) of $1855,{ }^{10}$ another widely read work, was his personal contribution to the Materialismusstreit ("materialism dispute"), a debate about religion, materialism and science that had been started by Göttingen's religious Professor of Medicine, Rudolph Wagner (1805-1864). ${ }^{11}$ The book was a polemic pamphlet against Wagner who had attacked Vogt personally. The first edition, published in January 1855, was such a success that a second edition followed in April, a third in May and a fourth in June. By publicly arguing for philosophical materialism, Vogt inevitably came into conflict with both the Catholic and the Protestant Churches. Vogt not only doubted the existence of God and called the Bible a book of myths, he also objected to such sacrosanct dogmas as the immortal soul and mankind's descent from Adam and Eve. In each foreword of the successive editions of Köhlerglaube und Wissenschaft, Vogt dealt anew with the massive amount of correspondence that his startling work was generating. By the appearance of the fourth edition, the book consisted of 65 pages of foreword and 124 pages of text. However, Vogt eventually grew tired of the feud - it began to bore him and he could no longer bear dealing with the barrowloads of letters that were being delivered to his home. ${ }^{12}$ Nevertheless, Vogt carried on the fight for his causes in other works; in particular, whenever Vogt thought the Church guilty of an abuse of power, he was not afraid to use strong language. In the popular work

${ }^{9}$ See Vogt, 1851a. The different translations of the Vestiges, including Vogt's, are analysed and compared in Rupke, 2000.

10 Vogt, 1855.

11 On scientific materialism in 19th-century Germany and the related controversies see Gregory, 1977. The relationship between the "quarrel of materialism" and the "quarrel of Darwinism" in the German states is explored in Junker, 1995, pp. 290-294.

12 See Vogt, 1859, p. xv. 
Untersuchungen über Thierstaaten (Inquiries into the States of Animals), for example, Vogt could not help crossing the borders of good taste by comparing clergymen to cockroaches:

Whatever these [Holy Communion] wafer guzzlers have caught sight of or grabbed, they do not let go of again. So pernicious, gnawing, scraping and destructive are they; on the other hand they are expert at ingratiating themselves. [...] Where the health of the mind stops, their influence starts. [...] As long as the animals are sick, they crawl to them in their places of refuge, they touch and stroke them with their antennae and pretend to be their friends; they ingratiate themselves in every way possible, blabber all kinds of nonsense about another world in which carnivorous insects would be punished for their sins and the herbivorous would be rewarded for their harmless character - but at the same time they keep a lookout for every opportunity, all points of entry and matters of secrecy, and, as a reward for their apparently selfless services, they are usually appointed heir by the dying. ${ }^{13}$

Although Vogt had not always supported evolutionary ideas, ${ }^{14}$ after the publication of Origin in 1859 he became an avowed Darwinist, arguing, from that day on, that Darwin had provided "with much ingenuity" a magnificent example as to how the world can do without God ${ }^{15}$ :

There can be no doubt that Darwin's theory ignores a personal creator, and his direct interference in the transformation and creation of species, there being no sphere of action for such a being.

13 The original wording in Vogt, 1851b, pp. 130-131: "Was diese Oblatenfresser einmal erspäht oder ergriffen haben, lassen sie nicht wieder los. So verderblich, nagend, schabend und zerstörend sie sind, so sehr können sie auf der anderen Seite sich einschmeicheln. [...] Wo die Gesundheit des Geistes aufhört, da fängt ihr Einfluss an. [...] Solange die Tiere krank sind, kriechen sie zu ihnen in ihre Zufluchtsstätten, betasten und streicheln sie mit den Fühlhörnern, stellen sich wie ihre Freunde, schmeicheln sich auf jede Weise ein, schwatzen ihnen allerlei Unsinn vor von einer anderen Welt, in welcher die fleischfressenden Insekten für ihre Sünden gestraft, die pflanzenfressenden für ihren harmlosen Charakter belohnt würden - dabei aber spähen sie alle Gelegenheiten, alle Zugänge und Verborgenheiten aus, und werden meistens zum Dank für ihre scheinbar uneigennützigen Dienste von den Sterbenden zu ihren Erben eingesetzt."

${ }^{14}$ On Vogt's attitude to evolutionary ideas before and after publication of Origin, see Rupke, 2005, pp. 151-155. Rupke argues that, originally, Vogt was an adherent of the theory of autochthonous generation, i.e. that species had appeared from dead matter by the spontaneous generation of their first seeds, germs, or primordial embryos. Only after reading Origin Vogt abandoned his opposition to the theory of evolution and became Darwin's ardent supporter.

15 Vogt, 1864, p. 446. 
Given the first starting point - the first organism - all existing organisms are subsequently, by natural selection, developed from it in a continuous manner through all geological periods by the simple laws of transmission. There arise no new species by any creative interference; none disappear by a divine mandate of destruction, since the natural course of things, the process of development of all organisms and the earth is amply sufficient for the production of all these phenomena. ${ }^{16}$

Vogt even developed his own ideas about the origin of mankind (a topic that Darwin had deliberately avoided in Origin): in 1863 Vogt published a collection of lectures, entitled Vorlesungen über den Menschen, which was translated, 1 year later, into English as Lectures on Man (1864). In this work, Vogt defended the view that different ape species had been the ancestors of the different human races. ${ }^{17}$ Thus, although Vogt, along with Thomas H. Huxley (1825-1895), who published Man's Place in Nature in the same year, became one of the first naturalists to apply Darwin's theory to the origins of humanity, his was a watered-down version, since Vogt readily accepted a teleologically directed evolution to account for his claim that the different human races originated independently of the different species of ape.

Vogt promoted his ideas about human origins in university lectures, academic articles and public talks. He also toured the German states, Austria, the Netherlands, Belgium and Switzerland as a campaigner for popular science in general, delivering speeches on the latest findings in the areas of geology, anthropology and biology to the public. ${ }^{18}$ Famous as the "prophète du matérialisme," he still vouched for a strict materialism, now having Darwinism to back up his ideas. ${ }^{19}$ As Vogt's son William reported in the biography of his father, the lectures aroused great public interest and split the opinions of his audience, so that journals that reported Vogt's lectures either praised or reviled them. On one occasion in Berlin a furious crowd allegedly assembled outside the

16 Vogt, 1864, p. 449.

17 Vogt, 1863, 1864.

18 Kockerbeck, 1999, pp. 23-24.

19 As Junker, 1995, argues, this combination of materialism, atheism and Darwinism was very common at that time in the German states.: Junker sees political circumstances in Germany, for example the 1848 Revolution, as one of the main reasons why the theory of natural selection was readily accepted there (in contrast, for example, to the course of events in France). As Junker maintains (p. 271), the liberals (such as Vogt) "used Darwinism to give their anti-religious and progressive program a naturalistic foundation." Similar theses, although not as elaborated in detail, have also been brought forward in Montgomery, 1972. 
hall in which Vogt was giving a lecture and threw stones at the windows; Vogt picked up one of the stones and, to the amusement of the audience, announced that "I told you yesterday about our savage ancestors from the Stone Age, [...] this period does not seem to be entirely over!",20

\section{In Search of a Translator}

As soon as the first wave of savage attacks and frenetic acclamation that greeted Origin in Britain was over, Darwin started to plan ahead, anxiously seeking the right translators to spread his ideas through the rest of Europe. As Janet Browne notes in her biography of Darwin, at that time "the initiative for foreign publication usually rested with the translator, who was expected to get permission directly from the author and negotiate a contract with a local publisher." ${ }^{21}$ However, Darwin by no means waited passively until somebody became interested in translating one of his works; rather, he sent out free copies to carefully chosen potential translators and asked his friends Huxley and Joseph D. Hooker (1814-1879) for recommendations. ${ }^{22}$ For the German edition, Darwin seems to have considered using the naturalist Albert von Kölliker (1817-1905) as a translator; yet, in the end it was the esteemed palaeontologist Heinrich Georg Bronn (1800-1862) who offered to undertake a German edition of Origin - an offer that Darwin gladly accepted. ${ }^{23}$ So Bronn's publishing company, the renowned E. Schweizerbart'sche Verlagsbuchhandlung, published the first two German editions of Origin, translated by Bronn, in 1860 and $1863 .^{24}$

However, although Bronn was a distinguished naturalist, he had reservations concerning Darwin's theory ${ }^{25}$ and had no compunction

${ }^{20}$ See W. Vogt, 1896b, pp. 177-178. The original wording on p.178: "Je vous parlais hier, dit-il avec à propos, des sauvages ancêtres de l'âge de la pierre; [...] cet âge là n'est pas encore tout à fait termineé!"

21 Browne, 2003, p. 140.

22 See Junker and Backenköhler, 1999, pp. 254f. Indeed, Junker and Backenköhler draw attention to the fact that a large part of Darwin's correspondence, hitherto neglected, deals with the topic of scientific translation, which demonstrates how important this aspect of publishing was for him (ibid., p. 252).

${ }^{23}$ For an analysis of this episode, see Junker, 1991.

24 The German editions of Origin were published as Darwin, 1860, 1863.

25 See Junker, 1991, which details Bronn's attitude towards evolutionary concepts. More recently, Bronn's views on the origin of life and species are discussed in Rupke, 2005 , pp. 149-151, in which it is stated that Bronn favoured an "autochthonous" theory on the origin of life and species, similar to the one that Vogt had endorsed before 1859. 
about making them explicit: rather than merely translating Origin, he added his own comments on some of the controversial topics that Darwin had consciously omitted, thereby producing an edition that contained many of Bronn's own philosophical arguments about the origin of life. Bronn even added a critical epilogue in which his ambivalent attitude towards Darwin's theory was unmistakable. ${ }^{26}$ Understandably, Darwin was not happy about this, and complaints concerning the quality of this translation would reach Darwin's home, Down House, over the course of the years, from several quarters. ${ }^{27}$

Bronn died in 1862, and it was not until 1866 that the publisher Christian Friedrich Schweizerbart (1805-1879) approached Darwin with the offer of publishing a third improved edition of Origin for the German market. Schweizerbart had heard that the head of the Hermann'sche Verlagsbuchhandlung in Frankfurt, Friedrich Emil Suchsland (1808-1903), had approached Darwin on the possibility of preparing a new and amended translation, which propelled Schweizerbart into immediate action. ${ }^{28}$ Note, that this time it was neither Darwin nor a translator who took the initiative, but the publishing houses themselves - it seems that publishing a translation of Darwin's books was at last considered interesting from a commercial point of view. ${ }^{29}$

Schweizerbart wrote to Darwin, asked him for amendments to the 1863 German version of Origin and recommended that the geologist Hans Bruno Geinitz (1814-1900) translate the altered parts of the book. ${ }^{30}$

${ }^{26}$ However, Junker, 1991, points out that Bronn's epilogue, although usually ignored in the literature, was by no means only dismissive but presented Darwin's theory as promising although requiring further elaboration.

${ }^{27}$ On complaints regarding Bronn's translations, see, e.g., E. Schweizerbart'sche Verlagsbuchhandlung to C. Darwin, 10 May 1866 (see also note 10); CCD, Vol. 14, pp. $166 f$.

${ }^{28}$ F. E. Suchsland to C. Darwin, 10 March 1866: "It is true that one German translation by Professor Bronn of Heidelberg already exists; but as it is not generally considered a successful reproduction, I think, another and more liberal translation has not only become a necessity for Germany considering the great importance and propagation of your theory there, but is also in your own interest." Cited Junker and Backenköhler, 1999, p. 259.

29 This point was also made in Junker and Backenköhler, 1999, p. 252.

${ }^{30}$ C. F. Schweizerbart to C. Darwin, 23 March 1866; CCD, Vol. 14, pp. 105f. As is explained in Junker and Backenköhler, 1999, p. 160, Geinitz had close ties with Schweizerbart, since he was, among other things, the editor of the Neues Jahrbuch für Mineralogie, Geognosie und Petrefaktenkunde, which was published jointly with Schweizerbart. Thus, Schweizerbart's choice of Geinitz as a translator was an obvious one, particularly given the fact that Schweizerbart had only a day to come up with a candidate. 
Given the choice of two publishers, Darwin picked Schweizerbart with whom he had worked before. Yet, Suchsland's son had warned Darwin about collaborating with Schweizerbart and Geinitz, not least because Geinitz opposed Darwin's theory (and Darwin had learned by painful experience, that is, by working with Bronn, what this could lead to); Suchsland himself would have commissioned the palaeontologist Friedrich Rolle (1827-1887), who had already published two popular introductions to Darwin's theory with Suchsland. ${ }^{31}$ The problem, however, was resolved, when Geinitz turned down the offer and recommended, in his place, Carus, an enthusiastic young naturalist who also supported the concept of natural selection. ${ }^{32}$

In his first letter to Darwin, Carus confirmed how pleased he was to undertake the new translation of Origin; at the same time he asked for permission to leave out Bronn's insertions - indeed, Carus was quite critical of the earlier German versions. ${ }^{33}$ Darwin's response shows that he was well aware of Bronn's unfortunate attempt to present Origin to the German public and that he was happy to accept Carus's help. ${ }^{34}$ As a result, Carus was given plenty of scope to change Bronn's versions; when he began working on the new translation, he kept in touch with Darwin regularly to discuss various details. The third German edition of Origin was published at the beginning of 1867 and Darwin was delighted with the result. $\mathrm{He}$ wrote to Carus in February 1867:

I heartily congratulate you that the main part of your labour is over: it would have been to most men a very troublesome task, but you seem to have indomitable powers of work. [...] I cannot sufficiently tell you how much I rejoice that you were persuaded to superintend the translation of the present edition of my book, for I

31 R. Suchsland to C. Darwin, 2 April 1866; CCD, Vol. 14, pp. 110f. R. Suchsland wrote on behalf of his father F. E. Suchsland. See also Junker and Backenköhler, 1999, pp. $260 \mathrm{ff}$.

32 E. Schweizerbart'sche Verlagsbuchhandlung to C. Darwin, 10 May 1866; E. Schweizerbart'sche Verlagsbuchhandlung to Charles Darwin, 26 October 1866; CCD, Vol. 14, pp. 166f. and pp. 362f.

33 See, e.g., Junker and Backenköhler, 1999, pp. $260 f$.

34 J. V. Carus to C. Darwin, 7 November 1866; C. Darwin to J. V. Carus, 10 November 1866; CCD, Vol. 14, pp. 378f., pp. 382f. Like others before him, Carus was highly critical of his predecessor's work. See J. V. Carus to C. Darwin, 15 November 1866; CCD, Vol. 14, pp. 388f.: "As for the translation I try to make it a really true one; to make it good, that is rather impossible without rewriting it. Yet I do my best to make it at any rate more German and readable. Some mistakes of Bronn's are quite ridiculous." 
have now the great satisfaction of knowing that the German public can judge fairly of its merits \& demerits. ${ }^{35}$

At the time Darwin wrote these lines, he had already been working on his large sequel to Origin for several years. By the end of 1866, he had finished Variation, although final revisions of the text kept him busy through 1867. While still working on the English version of Variation, Darwin had already received several requests from German publishers to translate the book. ${ }^{36}$ Darwin turned down all these offers and picked Schweizerbart again, on condition that the same translator (Carus) would be engaged. "If you inform me that he will translate it," Darwin wrote to Schweizerbart, "I would send you clean sheets." He even conceded that he "would give up any claim for payment if I could get a good translator." 37 Darwin also expressed his wish to have Carus as the translator in a letter to his British publisher, John Murray, telling him: "Please take no steps about the stereotypes [relief printing plates] until you hear from me again; as I said to him [Schweizerbart] I $w^{\mathrm{d}}$. not agree about Translation until I knew that a certain Prof. V. Carus $\mathrm{w}^{\mathrm{d}}$. undertake this \& that I have not yet heard." 38

Convinced of the importance of spreading Darwin's theory throughout the German states, Carus immediately wrote that he was willing to translate Variation..$^{39}$ Once again the arrangement seemed to be perfect and the translation of another work was set to begin - when a letter from Switzerland reached Down House on 8 April 1867, in which Vogt also made Darwin an offer. Vogt's publisher had informed him that Darwin was going to issue a new work and, knowing that Darwin's former translator Bronn had, in the meantime, died, Vogt wanted to learn if there was any possibility that he could introduce Variation to German-speaking Europe. Vogt avowed himself to be an ardent disciple of Darwin and called attention to his scientific reputation and his

35 C. Darwin to J. V. Carus, 17 February 1867; CCD, Vol. 15, p. 82.

36 Darwin had received an offer from Oldenbourg'sche Buchhandlung to translate Variation as early as October 1866, and his English publisher John Murray informed him in March 1867 that he had received another offer from an (unspecified) publishing house in Jena. See CCD, Vol. 15, p. 152 (note 3). On 8 May 1867, Darwin was approached by Nicholas Trübner, on behalf of a friend of his in Stuttgart, who was also keen to publish a German translation. CCD, Vol. 15, p. 252. On 29 May 1867, Murray forwarded Darwin an offer from an Austrian publisher, Tendler \& Co. CCD, Vol. 15, p. 283.

${ }^{37}$ C. Darwin to E. Schweizerbart'sche Verlagsbuchhandlung, 19 March 1867; CCD, Vol. 15, pp. 151f.

38 C. Darwin to J. Murray 4 April 1867; CCD, Vol. 15, p. 208.

39 J. V. Carus to C. Darwin, 5 April 1867; CCD, Vol. 15, pp. 209 f. 
experience in translating, having already distinguished himself as the translator of Vestiges and of Huxley's On our Knowledge of the Causes of the Phenomena of Organic Nature in $1865 .{ }^{40}$ Flattered by Vogt's enthusiasm, Darwin recalled that he had discerned a hint of uncertainty in Carus's last letter: "I am so very much occupied just now and within the next twelve month," Carus had written, "that I should feel exceedingly obliged if you would kindly tell me, at what rate your work will be published." ${ }^{41}$ Interpreting these words as a sign of a decline of interest on Carus's part, Darwin tinkered with the idea of switching to Vogt. In his rash response to Vogt of 12 April 1867, Darwin raised the hopes of the Geneva-based professor:

I look at it as a very great honour that a naturalist whose name I have respected for so many years should be willing to undertake the translation of my book. But Herr Schweizerbart, who published the Origin of Species applied to me some time ago, \& as he had persuaded Prof. Victor Carus to make the translation, I have agreed to his proposal. [...] Prof. Carus though he has undertaken the translation informs me that he has much work on hand, \& it is possible (though not probable) that when he hears (\& I wrote to him on the subject yesterday) of the size of the book, \& that several sheets will be printed immediately \& sent to him, he may wish to give up the task. In that case nothing $\mathrm{w}^{\mathrm{d}}$ give me higher satisfaction than that Schweizerbart $\mathrm{sh}^{\mathrm{d}}$ arrange with you, if that be possible, for a translation; for I have often heard of the fame of your excellent translations. ${ }^{42}$

Thus, everything depended on Carus's reaction to learning that Darwin might hand over the translation work to Vogt. And Carus, far from breathing a sigh of relief, was filled with indignation when he heard of Vogt's meddling. He immediately wrote back to Darwin, announcing that he would have no trouble at all carrying out the translation and offered to finish the German version of Variation without any delay. ${ }^{43}$ Carus stressed that it was undoubtedly up to Darwin to choose between the two candidates and he admitted that Vogt was much better known than he was; however, Carus also made it clear that he would be extremely disappointed if Darwin were to decide on Vogt - and not only

\footnotetext{
${ }^{40}$ C. Vogt to C. Darwin, 8 April 1867; CCD, Vol. 15, pp. 214f.; for the English translation, see pp. 501f.

41 J. V. Carus to C. Darwin, 5 April 1867; CCD, Vol. 15, pp. $209 f$.

42 C. Darwin to C. Vogt, 12 April 1867; CCD, Vol. 15, p. 220.

43 J. V. Carus to C. Darwin, 15 April 1867; CCD, Vol. 15, p. 223.
} 
for his own sake, as Carus was quick to explain: "By his unmeasured satyrical and I am sorry to say sometimes quite cynical extravagance," Carus wrote about Vogt, "he lost a good deal of the influence, his judgement could otherwise still have. [...] I should be sorry for your work's sake, if it should be associated with the name of a man, who would contrast by his fighting and scoulding manners most singularly with the sober and earnest tenor of a book full of observations." 44 Realising that Carus had been enraged rather than relieved by his letter, Darwin replied apologetically: "The wish never for a moment crossed my mind that Vogt should translate in preference to you; [...] As you are not frightened at the undertaking, I sh ${ }^{\mathrm{d}}$. be most truly grieved that there should be any change." 45 In the same letter Darwin informed Carus about the availability of proofs, which implied that the question of who would translate Variation had finally been settled.

Only a few days later, however, Darwin received another letter, in which Vogt had a new proposition: Charles-Ferdinand Reinwald (b. 1812, date of death unknown), Vogt's Parisian publisher, was interested in bringing out a French edition of Variation and Reinwald had suggested that Vogt's former student, Jean-Jacques Moulinié (1830-1872), could undertake the translation work, with Vogt editing it and adding a preface. ${ }^{46}$ Vogt wrote that Moulinié was an exceptionally good choice, since he had native fluency in English and French, and he had plenty of time to devote himself to the translation. Unfortunately, Darwin's response to this offer of Vogt has not been found, but another letter from Reinwald, written in May 1867, makes it clear that Darwin, Vogt, Moulinié and Reinwald had come to an arrangement. "I am highly gratified by this kind proposal," Reinwald wrote to Darwin, "which I accept with pleasure for my part, and hope that Prof. Carl Vogt will not only give his advice to our French translator Col. Moulinié, but allow me to put his name on the title piece as being done under his direction." ${ }^{, 47}$ As planned, Vogt edited Moulinié's translation and added a preface and, as Reinwald had wished, the words "Préface de Carl Vogt," appeared on the title page when the book was published in $1868 .^{48}$

\footnotetext{
44 ibid.

45 C. Darwin to J. V. Carus, 18 April 1867; CCD, Vol. 15, p. 228.

46 C. Vogt to C. Darwin 23 April 1867; CCD, Vol. 15, pp. 233f; for the English translation, see ibid., pp. 503f.

47 C.-F. Reinwald to C. Darwin, May 1867; CCD, Vol. 15, p. 245.

48 The French edition was published as Darwin, 1868.
} 


\section{A Collaboration Against All Odds}

The stark contrast between Vogt's and Darwin's characters was most visible in their attitude towards religion: although both of them had lost their faith in the Christian God and Church, they dealt very differently with this issue. As was described earlier, Vogt publicly excoriated religion. Darwin, on the other hand, always skirted the subject; believing like many of his contemporaries - that faith was a personal matter, he did not regard it appropriate to include anti-religious statements in his scientific works. ${ }^{49}$ For example, when Darwin's son George wanted to publish an article containing disparaging remarks on prayers, divine morals and the afterlife, the worried father considered the "moral problem" of speaking out on religion as "frightfully difficult" and advised prudence: "I $\mathrm{w}^{\mathrm{d}}$. urge you not to publish it for some months, at the soonest, \& then consider whether you think it new \& important enough to counterbalance the evils." 50 On another occasion, when Darwin's colleague George Romanes (1848-1894) was proposing to publish a strident refutation of theism, Darwin strongly advised him to do so anonymously. ${ }^{51}$ Darwin also tried to avoid public disputes on other topics, creating an image of himself as the perfect gentleman scientist; Vogt, by contrast, never shied away from conflict and was not in the slightest bit troubled by his notorious reputation.

At first glance the most likely scenario is as follows: a prudent Darwin turned down a provocative Vogt on tactical grounds so as to avoid any possible scandal that would connect Darwin's name to vulgar materialism or vile blasphemy. Thus, from this perspective, making any arrangements with Vogt would have been out of the question. This is more or less how the scenario is usually framed. However, if we take a closer look at the incidents surrounding Vogt's rejection as a translator, as described in section "In Search of a Translator", this interpretation does not fit the facts. Let us recall: after Carus had agreed to translate Variation, Darwin should have been relieved to have acquired the services of a competent translator, whose work he already knew. These circumstances would have provided him with the ideal opportunity to decline Vogt's offer to translate Variation politely; however, instead of giving Vogt short shrift, Darwin informed him that it would be both honourable and exceedingly satisfying for him to acquire the services of

49 On Darwin's attitude to religion, see, e.g., Brooke, 2003.

${ }^{50}$ C. Darwin to G. Darwin, 21 and 24 October 1873; cited Desmond and Moore, 1992, p. 602.

51 Desmond and Moore, 1992, p. 623, pp. 632f. 
Vogt as a translator, in the event that Carus would turn down the work. Only when it became obvious to Darwin that Carus was outraged at the knowledge that Vogt might replace him, did Darwin revert to caution again and decline Vogt's offer to translate Variation into German.

One might surmise that Carus's angry reply had woken Darwin up to reality; maybe Darwin only realised the dangers of collaborating with Vogt after having heard Carus's scathing remarks concerning Vogt's behaviour. However, later correspondence between Darwin and Vogt makes this interpretation implausible. Darwin not only toyed with the idea of having Vogt translate Variation; a few days later he accepted Vogt as collaborator for the French version of the book. Moreover, it was not only agreed that Vogt's former pupil Moulinie should undertake the translation, but that Vogt himself should edit it and add a preface. If Darwin had been truly concerned about Vogt's bold language and political radicalism, he would hardly have given Vogt the freedom to write a preface. For Vogt would have had much more opportunity to express his controversial opinions in an introductory preface than in a translation; and Darwin was well aware, from previous experience, that many translators did not have misgivings about writing prefaces or comments that did not reflect the author's point of view. 52

The supposed basis for Darwin's rejection of Vogt becomes even more implausible if one considers that, in 1872, Darwin also agreed to Vogt writing the preface to the French version of Descent, another major work of his. ${ }^{53}$ Three years earlier, in 1869, after hearing that Darwin was planning to publish a work on the origin of mankind, Vogt had offered his services as a German translator. In Vogt's letter to Darwin (October 1869), it is clear that Moulinié had already been in touch with Darwin regarding a French version of Descent:

Mr. Mouliné has already written to you, I believe, on the subject of the French translation of your book on man [...] I believe that you have been satisfied with the translation he produced. He will give the same care to this book as he gave to that on domestication. $[\ldots]$

52 Bronn's epilogue, which was added to the first two German editions of Origin, and Clemence Royer's preface to the first French edition of the same work are but two examples of Darwin's bad experiences with collaborators.

53 The English original was published in 1871 . For a recently published edition, see Darwin, 2004. 
You told me when I wrote to you about the translation of your book on domestication that you were committed to Mr. Carus and Mr. Schweizerbart. I do not know if this engagement continues to hold for the new book [...] I would in no way wish to step on the toes of Mr. Carus, a worthy and courageous young man who was rejected from the chair of Zoology at Leipzig certainly to a great extent because he loudly espoused your doctrines instead of following the official line as his successful rival Mr. Leukart did. Mr. Carus told me last year at Norwich that he would do no more translations but I think that was in the hope of being named to the lectureship. But in the present state of things, so annoying for him, I do not know if he might not have changed his resolution. But I believe in any case that I ought to absent myself in case he might have expressed a wish to do a translation of your new work, and should that be so, pretend that I said nothing. ${ }^{54}$

In fact, Carus had never been given the professorship for Zoology at Leipzig to which Vogt alluded in this letter, although he had been promised the position earlier; moreover, although Carus was still Professor of Comparative Anatomy at Leipzig, his position was, in his own words, "far from being so agreeable" as it had been before. ${ }^{55}$ Carus told Darwin that he would gladly accept the offer to translate Descent and

${ }^{54}$ C. Vogt to C. Darwin, 26 October 1869; Cambridge University Library, DAR 180:13. Translated by the Darwin Correspondence Project. The original wording: "Monsieur Moulinieé vous aura écrit, je pense, au sujet de la traduction française de votre livre sur l'homme [...] je pense que vous avez été content de la traduction qu'il a faite et il mettra autant de soins à ce livre comme à celui sur la domestication. [...] Vous me répondîtes, lorsque je vous écrivais au sujet de la traduction de votre livre sur la domestication, que vous étiez engagé avec Mes. Carus et Schweizerbart. Je ne sais, si ces engagements continuent pour votre nouveau livre [...] je ne voudrais en aucune façon aller sur les brisées de Mr. Carus, digne et brave garçon, qui a eu le grand malheur d'avoir été écarté de la chaire de zoologie à Leipzig et cela certainement en grande partie parce qu'il a professé hautement vos doctrines au lieu de suivre l'ornière officielle comme son concurrent victorieux Mr. Leukart. Mr. Carus m'avait dit, l'année passée à Norwich, qu'il ne ferait plus de traductions - je pense que c'était dans l'espoir d'être nommé à l'Ordinariat - je ne sais si dans les circonstances actuelles, si fâcheuses pour lui; il n'aura changé de résolution. Mais je crois en tout cas de mon devoir de m'abstenir en cas où il vous aurait manifesté le désir de faire la traduction de votre nouvel ouvrage et si cela était, mettez que je n'ai rien dit."

55 J. V. Carus to C. Darwin, 6 November 1869; Cambridge University Library, DAR 161:73. 
Darwin, eager to support Carus during this difficult period, negotiated a contract with him. ${ }^{56}$ And, as Darwin wrote to Vogt, the collaboration between Carus and Darwin had already been "partly agreed." 57

Nevertheless, Vogt did not miss out, either: he was engaged for a second time to revise Moulinié's translation and to write a preface to the French version of Descent. At the same time, Moulinié was also offered the opportunity to undertake a new translation of Origin, and Darwin made it clear that he wished to work with Vogt again: "If Prof. Vogt will aid you $I \operatorname{sh}^{d}$ think it $\mathrm{w}^{\mathrm{d}}$ be a great advantage, $\&$ his name is a tower of strength." 58

Consequently, Vogt and Moulinié worked together between 1869 and 1872 on these tasks, despite the difficulties caused by the FrancoPrussian War in 1870 and Moulinié's ill-health. ${ }^{59}$ In 1872, Moulinié's illness worsened and in September his publisher Reinwald informed Darwin that Moulinié's mental faculties had been strongly weakened. ${ }^{60}$ In December 1872 Moulinié died at the age of 42 years, leaving both translations unfinished. His translation of Descent, containing Vogt's preface, came out in 1872 but was not highly regarded. ${ }^{61}$ Edmond Barbier edited the text, and an improved version of the book was released in two volumes in 1873 and 1874. Moulinié's translation of Origin also had to be revised before the new edition could be published in 1873 (see Table 1). ${ }^{62}$ During the next few years, it was Barbier who prepared the new French editions of Origin, Variation and Descent;

56 C. Darwin to J. V. Carus, 30 October 1869; Berlin, Deutsche Staatsbibliothek, Darmst. 1918.214, Carus 23; C. Darwin to J. V. Carus 9 November 1869; Berlin, Deutsche Staatsbibliothek, Darmst. 1918.214, Carus 24.

57 C. Darwin to C. Vogt, 30 October 1869; Genève, Bibliothèque Publique et Universitaire, Ms. fr. 2188, ff. 298-299: Charles Darwin. L.a.s. à Carl Vogt. Down Beckenham (Kent), 30 Oct. 1869.

58 C. Darwin to J.-J. Moulinié, 15 November 1869; Genève, Bibliothèque Publique et Universitaire, Ms. suppl. 66, ff. 11-12: Charles Darwin. L.a.s. à Jean-Jacques Moulinié. Down Beckenham (Kent), 23 Oct. 1869.

59 C.-F. Reinwald to C. Darwin, 1 February 1871; Cambridge University Library, DAR 176:93; C.-F. Reinwald to C. Darwin, 4 March 1873; Cambridge University Library, DAR 176:99.

${ }^{60}$ C.-F. Reinwald to C. Darwin, 17 September 1872; Cambridge University Library, DAR 176:95.

${ }^{61}$ The book was published as Darwin, 1872. On complaints regarding Moulinié's translation of Descent, see Jeanblanc, 1999, pp. 189-190; F. Baudry to C. Darwin, 4 December 1872; Cambridge University Library, DAR 160:95; C.-F. Reinwald to C. Darwin, 14 May 1873; Cambridge University Library, DAR 176:100.

${ }^{62}$ C.-F. Reinwald to C. Darwin, 23 November 1872; Cambridge University Library, DAR 176:98. 
Table 1. The French translations of Darwin's major works, 1868-1891

\begin{tabular}{llll}
\hline Book & Year & Translator & Writer of Preface \\
\hline Variation & 1868 & Moulinié & Vogt \\
Descent of Man & 1879 & Barbier & Vogt \\
& 1872 & Moulinié & Vogt \\
& $1873-1874$ & Moulinié/Barbier & Vogt \\
& 1881 & Barbier & Vogt \\
Origin of Species & 1891 & Barbier & Vogt \\
& 1873 & Moulinié & Other/none \\
& 1876 & Barbier & Other/none \\
& 1880 & Barbier & Other/none \\
& 1882 & Barbier & Other/none \\
& 1887 & Barbier & Other/none \\
\hline
\end{tabular}

however, Vogt's prefaces, in all the later French editions both of Variation and Descent, were left untouched.

Thus, it would seem that Darwin was quite keen on collaborating with Vogt: he almost engaged him as a German translator; he explicitly wished that Moulinié, the French translator of his major books, should work with Vogt; and he engaged Vogt to write the prefaces to these editions. Considering these facts, Vogt's outspoken language and controversial reputation cannot have offended Darwin that much.

\section{A Pig in a Poke?}

Two different scenarios may account for Darwin's attitude towards Vogt: either Darwin was unaware of Vogt's propensity to bring in the heavy artillery when writing on materialism and atheism; or, Darwin was familiar with the displeasing aspects of Vogt but had decided that the advantages of collaborating with him outweighed the disadvantages. To estimate how aware Darwin was of Vogt's conduct prior to 1867, it is necessary to find out which of Vogt's texts found their way onto Darwin's desk and what he had learned from friends and correspondents about the Swiss-German naturalist.

It was Huxley who in 1854 first drew Darwin's attention to Vogt: Darwin had wanted to send copies of the second edition of his book on barnacles to continental naturalists and he had asked Huxley to provide him with the names of possible candidates. Vogt was included among the recommended naturalists, and another letter to Huxley reveals that Darwin did, indeed, send Vogt a copy of this book. ${ }^{63}$ In December 1858,

63 C. Darwin to T. H. Huxley, 2 September 1854; C. Darwin to T. H. Huxley, 13 September 1854; CCD, Vol. 5, pp. 212f., pp. $219 f$. 
Huxley also pointed out to Darwin that Vogt had written an article on the development of swim bladders in fish. Furthermore, Vogt's name appears on an 1864 list of naturalists who Darwin had selected to receive a copy of his article "Three Forms of Lythrum Salicaria," a study on crossing experiments in flowers. ${ }^{64}$ Therefore, it is highly likely that Darwin had read at least one of Vogt's zoological articles in the late 1850 s or early 1860 s. They were written in French, in German and, in at least two cases, in English, but all were short studies of fish and mussel anatomy or of behavioural research on cuttlefish and jellyfish. The texts would have revealed Vogt's talent as a naturalist but nothing about his sharp tongue or political disposition.

However, this situation certainly changed in 1864 on publication of Vogt's Lectures on Man; besides including comments on human evolution, the functions of the brain and comparisons between the people of the world, it also gave an indication of Vogt's anti-religious and materialistic attitude and his polemical style of writing.

The English version of Lectures on Man was published by the Anthropological Society of London and translated by its then president, James Hunt. Both Hunt and the society in general were notorious for their extreme racism, which went far beyond usual 19th-century attitudes. ${ }^{65}$ Hunt had been interested in this work because Vogt used parts of Darwin's theory to support a polygenistic attitude towards the origin of mankind, that is, Vogt defended the view that humanity could be divided into different species with varying origins and traits. This view was, of course, at odds with Darwin's own belief - if Darwin's theory was taken seriously, also in application on human beings, a monogenetic view of the origin of mankind was inevitable, as adopted by, for example, Huxley and, later, also Darwin himself. ${ }^{66}$ Yet, the Anthropological Society was unworried by these difficulties - they were pleased to learn that polygenism could have its origins in any kind of

${ }^{64}$ T. H. Huxley to C. Darwin, 17 December 1858; CCD, Vol. 7, 217f. For the list of naturalists, see CCD, Appendix to Vol. 12, pp. 495-499.

${ }^{65}$ On the radical racism of the Anthropological Society, see, e.g., Richards, 1989, and Stocking, 1987, pp. 251-253.

${ }^{66}$ Although Vogt was convinced of the existence of different human species, he maintained that, during a later stage of evolution, these species gradually came to resemble each other more closely and will do so even more in the future. Darwin was fully aware of Vogt's hypothesis and even mentioned it in his Descent, although he did not endorse it: "It is however possible, though far from probable, that the early progenitors of man might formerly have diverged much in character, until they became more unlike each other than any now existing races; but that subsequently, as suggested by Vogt, they converged in character." Darwin, 2004, p. 206. See also Vucinich, 1972, p. 236; Richards, 1989, pp. 417-419. 
"Darwinism," since the latter was becoming increasingly popular. One should note, however, that Vogt's viewpoint on racism - that it was a possible consequence of polygenism - differed greatly to that of the Society. ${ }^{67}$ Among other things, Vogt was clearly critical of slavery, which many Anthropologists strongly endorsed. Thus, the translator, Hunt, could not help adding a note to a pertinent passage in Vogt's book, in which he, unlike Vogt, defended slavers, explaining that "they [the slavers] believe that the Negro mentally is only a child, and quite incapable of living happily and naturally in juxtaposition with the white European, except in a state of complete subordination and subjection." 68

Generally speaking, Vogt's Lectures on Man was a large collection of scientific data, but Vogt could still not refrain from inserting taunting statements about the Church and religious beliefs. Although in his translation Hunt tried to play down delicate passages (for example, by translating "gläubiges Gesindel" [devout vermin] as "pious ignorance"), Vogt's hostile attitude towards religion was unmistakable. ${ }^{69}$ Hunt even called attention to Vogt's polemical character in the preface:

The author is not simply a fearless writer, but his tone will, I imagine, occasionally be offensive both to the general and scientific reader. [...] If M. Vogt had been an Englishman I should certainly have highly censured a man of such profound and extensive views for wasting his energies in attacking the opinions of theologians (as such) respecting scientific facts or scientific deductions. ${ }^{70}$

As a consequence, Hunt chose to omit some of the most offensive passages in the main body of the text, and placed them instead in an appendix that immediately followed Vogt's last chapter. However, this way of dealing with the problem exposed Vogt's displeasing style even more clearly, since now some of the "best" examples of the author's bad taste could be seen at a glance. Here, readers could discover, for instance, that Vogt regarded it as appropriate to praise:

\footnotetext{
${ }^{67}$ Many texts on 19th-century polygenism unfortunately fail to make a clear distinction between Vogt's polygenism and the polygenism of the Anthropological Society. See, e.g., Richards, 1989, pp. 418-419 and Bowler, 1986, pp. 132-133. Incidentally, the very fact that Vogt agreed to have his work translated by Hunt, who had a political agenda very different to his own, shows how difficult it was to find sympathetic translators.

68 Vogt, 1864, p. 18.

${ }^{69}$ See Vogt, 1863, p. 7, for the German original and Vogt, 1864, p. 9, for the English translation.

70 Vogt, 1864, pp. xii-xiv (Hunt's preface).
} 
... the ape type in man, just as the pious painter of the Byzantine school and our present Nazarenes act in depicting their Saviours and Madonnas, with their courts of saints, with long narrow apehands and feet, and orang-utan pelves [sic], which warrant the immaculate conception, since no human head could pass through. ${ }^{71}$

Readers would also have found the fearless author gloating over the fact that the ape Ateles belzebuth, in German called Teufelsaffe (devil's ape), has a close affinity with man; Vogt commented that: "Properly speaking, my human character is here gone to the devil! No operculum, - no covered transition convolution! To the devil with that devil's ape! But we see how nature indicates here that the devil stands nearest to the man!"72

This practice of Hunt's did not go unnoticed. When Darwin's friend and correspondent Edward Cresy recommended Vogt's Lectures on Man to Darwin in September 1865, Cresy made fun of Hunt's clumsy attempts at censorship and compared Vogt's style with that of Huxley's - note that Cresy did not expect Darwin to take offence but rather to be amused:

I brought Vogt's lectures on man just published by the Anthropological Society with me to read here [...] If you have not read him you will be amused at his Huxleyan outspokenness, still more at the excessive naïvité of the translator $\mathrm{D}^{\mathrm{r}}$ James Hunt who struck out a few passages as likely to offend pious people but to mollify the savant's indignation at his want of courage he his printed the omitted matter in the Appendix! Though why these should horrify people more than much which he has left in puzzles me to see. ${ }^{73}$

One of the sensitive passages that remained in its original context was Vogt's justification as to why "Apostle skulls" was the right term for some "simious" skulls found in Switzerland: "I imagine that in life they must have resembled the type of Peter the Apostle."74

After having read Lectures on Man, Darwin would have known about Vogt's marked preference for polemical comments, since the extensive marginalia in his copy show that Darwin thoroughly examined the

71 Vogt, 1864, p. 470.

72 Vogt, 1864, p. 470.

73 E. Cresy to C. Darwin, 10 September 1865; CCD, Vol. 13, pp. 230 f.

74 Vogt, 1864, p. 378. 
475-page book. ${ }^{75}$ But, as Cresy had expected, Vogt's insertions do not appear to have received any special attention from Darwin - at least he did not mark them in any way. Darwin would typically pencil in numbers next to important passages and then write out his comments on a separate sheet of paper, which he placed at the end of the book ${ }^{76}$; in Lectures on Man, Darwin marked scientific observations that were new to him but not one of Vogt's "offensive" statements.

Indeed, having read Lectures on Man, Darwin seems to have become increasingly interested in Vogt as a man of science, especially after the summer of 1867, when Darwin read Vogt's latest work Mémoire sur les microcéphales (Memoir on the Microcephalics), ${ }^{77}$ which the Swiss-German naturalist had sent him as a gift. This was a study on the reappearance of primitive traits in modern humans, which, Darwin told Vogt, "has interested me extremely. It is really curious how closely we have considered the same classes of facts, \& have come to similar conclusions." ${ }^{, 78}$ Darwin kept his copy, together with its review by JeanLouis Armand de Quatrefages (1810-1892); and wrote on the title page of the latter: "Quatrefages on Vogt on Man (important)," with the word "Man" underlined twice. ${ }^{79}$ Vogt's research and thoughts on mankind were evidently of great interest to Darwin while he was planning Descent, in which he would quote several passages from Vogt's books. ${ }^{80}$ Further evidence for Darwin's continued interest in Vogt can be found in his preserved correspondence. In November 1867 the American Charles Loring Brace (1826-1890) promised that he would send Darwin a critical article on the work of German Darwinians, which included Ernst Haeckel, Ludwig Büchner and Vogt. Darwin curiously awaited the article and jotted down Vogt's name in ink at the top of Brace's letter. ${ }^{81}$ Note that Darwin's clear interest in Vogt's work coincided with their first collaborative venture and with the planning of Descent.

Thus, at first glance, Darwin seemed to be totally indifferent towards Vogt's outspoken language but rather held him in high esteem because of

75 It was possible to examine this copy, which is located in the Cambridge University Library. Darwin himself assured Vogt in April 1867 that he had read the English translation of Lectures on Man with "extreme interest"; C. Darwin to C. Vogt, 12 April 1867; CCD, Vol. 15, p. 220.

${ }^{76}$ On Darwin's reading habits and his marginal notes, see Di Gregorio, 1990, pp. xiixxxvii.

77 Vogt, 1867.

78 C. Darwin to C. Vogt, 7 August 1867; CCD, Vol. 15, pp. 342 f.

79 Quatrefages, 1867. Copy preserved in Cambridge University Library.

${ }^{80}$ See Darwin, 2004, pp. 35, 54, 109, 206, 622, 625, 631 and 645.

81 C. L. Brace to C. Darwin, 14 November 1867; CCD, Vol. 15, pp. $426 f$. 
his scientific achievements. However, one has to bear in mind that it is almost certain that Darwin never caught sight of the libertine's most extreme passages, such as those in Untersuchungen über Tierstaaten; such statements only appeared in Vogt's political and philosophical writings and in German, a language that Darwin could barely read. However, Darwin was made aware of this side of Vogt's work through his correspondents. In addition to Carus's angry letter (discussed earlier), the Dutch botanist Frederick Antony Hartsen (1838-1877) cautioned Darwin in 1869 about the potential dangers of associating himself with Vogt: "Carl Vogt has given lectures in Holland and in doing so he has interweaved your theories with his materialism. Thus some people are brought to the opinion that materialism and atheism are the last word of Darwinism." 82 And according to Desmond and Moore, Darwin at least once openly expressed his dismay about Vogt and his polemical rhetoric: "[Darwin] told Frances Cobbe that Vogt in London 'gave a lecture, in which he treated the Mass as the last relic of that Cannibalism which gradually took to eating only the heart, or eyes of a man to acquire his courage.' Darwin's only comment was 'how much more decency there was in speaking on such subjects in England'." ${ }^{83}$ Yet despite all of this, Darwin did not show any sign of wanting to end his association with Vogt.

To understand Darwin's relationship with Vogt, one has to take into consideration that Darwin could benefit greatly from it. Vogt was gifted in languages and his translations were considered faithful; according to the historian of science Nicolaas Rupke, it was Vogt's second German translation of Robert Chambers's Vestiges that had come closest to the original. ${ }^{84}$ Vogt's work also received praise from other quarters. The German publisher Rudolf Oldenbourg (1887-1921), for example, informed Darwin in 1868 that his works in the past had been translated very poorly into German, while at the same time he indirectly praised Vogt as a translator. Oldenbourg wrote:

${ }^{82}$ F. A. Hartson to C. Darwin, 15 February 1869; Cambridge University Library, DAR 166:114. Translated by the Darwin Correspondence Project. The original wording: "Carl Vogt hat in Holland Vorlesungen gehalten und darin Ihre Theorien mit seinem Materialismus verwebt. Manche Leute sind dadurch veranlasst zur Ansicht dass Materialismus und Atheismus das letzte Wort des Darwinismus ist."

83 Desmond and Moore, 1992, p. 573.

${ }^{84}$ Rupke, 2000, p. 217. "To Sedgwick, Whewell and other concerned dons the real purport of the book was more accurately expressed by the preface to the second German translation. [...] The second German translator was none other than the notorious materialist and anti-monarchist rebel, Carl Vogt." Adam Sedgwick (1785-1873) and William Whewell (1794-1866) were Cambridge professors who strongly opposed theories of evolution. 
I recollect, that when 12 years ago I read your journey in South America, translated by Dieffenbach, I could not help smiling at the remarquable awkwardness of poor Mr. Dieffenbach's translation, who in a life of travel-toil had forgot his german. More serious are the insufficiencies of Mr. Bronn's translation of your "origin" because they have actually caused misunderstandings and doubts. [...] Your friend Prof Huxley was much better introduced into the german world. ${ }^{85}$

Huxley's works, to which Oldenbourg referred in this letter, had been translated by Carus and Vogt - the same two naturalists who would later compete for Darwin's favour. It is worth recalling that in his first letter to Vogt, Darwin remarked that "I have often heard of the fame of your excellent translations." ${ }^{\prime 86}$ Given the reputation of Vogt's work, Darwin's statement was very probably more than just good manners.

However, it was not only because of his gift for languages that Vogt could be considered an excellent choice. Darwin knew of Vogt's enthusiasm for Darwinism and realised that, as an accomplished man of science, Vogt had understood the principle of natural selection and its consequences. Thus, when Vogt recommended Moulinié to undertake the translation work, a certain standard of scientific quality was guaranteed. This was especially important in France, because earlier French editions of Origin had been badly translated. The translations by Clemence Royer (1830-1902), a self-taught philosopher and sociologist, had turned out to be excessively laced with social theories, and showed such a lack of scientific understanding that many of Darwin's carefully conceived scientific terms had been totally mistranslated. ${ }^{87}$ The team of Moulinie and Vogt, both of them naturalists, provided an excellent opportunity to set the matter to rights - Vogt's letter to Darwin, in which he first suggested Moulinié as a potential translator, explicitly stated that Moulinié's translation would be better "than the one $\mathrm{M}^{\text {lle }}$ Royer did for his [Darwin's] book on species." 88

That Darwin was not troubled about engaging political activists as translators can be taken from the example alluded to by Oldenbourg

85 R. Oldenbourg to C. Darwin, 28 October 1866; CCD, Vol. 14, p. 364.

${ }^{86}$ C. Darwin to C. Vogt, 12 April 1867; CCD, Vol. 15, p. 220.

87 See, e.g., Browne, 2003, p. 142. According to Browne, Darwin considered this French edition to be a "travesty of his views." For more details of Royer's translation and the difficulties Darwin had finding a translator in France, see also Stebbins, 1972; for a comprehensive biography of Royer, see Harvey, 1997.

88 C. Vogt to C. Darwin, 23 April 1867; CCD, Vol. 15, pp. 233f. For the English translation, see ibid., pp. 503f. 
(see letter quoted above) - although it is not quite as pointed as the case of Vogt. Darwin's first book, the Journal of Researches (1839), was translated by the German naturalist Ernst Dieffenbach (1811-1855). Interestingly, Dieffenbach's curriculum vitae closely resembled that of Vogt. Like Vogt, Dieffenbach had to leave the town (Giessen), where he was doing his medical studies in the 1830s because of his political involvement in democratic circles. Dieffenbach also first went into exile in Switzerland (Zurich), before he was spotted by the German police and moved on to London. In 1839, he was given the leadership of a 2-year-expedition to New Zealand - this obviously qualified him very well for translating Darwin's book, which was an account of his journey on the HMS Beagle. Thus, when Dieffenbach offered to undertake this translation in 1843, Darwin gladly - and promptly - accepted. ${ }^{89}$

The very fact that the same people received commissions to translate natural history works from several parties is evidence of how difficult it was to find good translators - not to speak of those who were, in addition, respectable. Vogt himself had translated Vestiges and Huxley's work. Moulinié was not only Vogt's former student; he had also translated Vogt's Vorlesungen über den Menschen into French before turning his attention to Darwin's works. ${ }^{90}$ The Russian translator of Vogt's book, Vladimir O. Kovalevsky, translated several of Darwin's works into Russian; he was also the translator of part of the renowned zoological work Brehm's Thierleben (Brehm's Lives of Animals). ${ }^{91}$ And, finally, Carus had also established himself as Huxley's translator before being engaged by Darwin. In a letter to Huxley, Darwin clearly expressed his frustration with the whole translation business: "I have had endless bother about French Translation, [...] which makes me gladder to close with any one for German Translation." 92 Remember that Darwin had written that he would even refrain from charging for

89 See Junker and Backenköhler, 1999, pp. 252ff.

90 See, e.g., CCD, Vol. 15, Introduction, p. xvii.

${ }^{91}$ On Kovalevsky as Darwin's translator, see, e.g., CCD, Vol. 15, Introduction, p. xvii. Kovalevsky wrote to Darwin about Brehm's Thierleben on 15 May 1867 and suggested that he could include some of the woodcuts for the Russian edition of Variation. CCD, Vol. 15, pp. 260f. Kovalevsky mentioned the work he had done for Vogt and others in a letter to Darwin of 21 March 1867, proposing that he would be willing to work on the same terms for Darwin, CCD, Vol. 15, pp. 204f. See also note 6. See Vucinich, 1988, for a comprehensive treatment of the spread of Darwinian ideas in Russia.

${ }^{92}$ C. Darwin to T. H. Huxley, 4 February 1860; CCD, Vol. 8, pp. $70 f$. 
the German translation if only Schweizerbart could find a competent translator. ${ }^{93}$

Vogt's far-reaching fame as an established naturalist and popular speaker of science was also useful to Darwin, especially in France, where Lamarckism was still popular. And it was precisely in France, where Vogt was well known. ${ }^{94}$ In 1867 , the year he first made himself available as Darwin's translator, Vogt was awarded the "Prix Godard" by the Anthropological Society of Paris for his Mémoire sur les microcéphales. ${ }^{95}$ Reinhard's decision to print Vogt's name on the cover of Moulinié's translation is clear evidence that the Swiss-German naturalist's reputation was considered a selling point. Darwin revealed that he was aware of this when he thanked Vogt for offering to translate Descent into German, feeling "certain that it would have made my book much more widely known." 96

Considering these facts, it would seem that the two alternative scenarios raised at the beginning of this chapter both seem true in part: most probably, Darwin was not fully aware of Vogt's capacity to attack religion and the Church, although he did know of the materialist's outspokenness and, consequently, realised that cooperating with Vogt would involve the risk of displeasing some of his readers. However, the advantages of collaborating with him on his French translations obviously greatly outweighed the disadvantages.

\section{Conclusion}

The preface to the French edition of Variation proved that Darwin's decision to accept Vogt had been the right one. Over 16 pages, Vogt praised Darwin's contribution to 19th-century science and drew attention to the English naturalist's good scientific practice. Vogt's most intemperate statement was his demand that opponents of Darwinism should be sent back to school; his preface certainly did not damage Darwin's reputation. ${ }^{97}$ Vogt seemed to be much more reserved when he

93 C. Darwin to E. Schweizerbart'sche Verlagsbuchhandlung, 19 March 1867; CCD, Vol. 15, pp. 151f. As a consequence, Darwin also waived the charge on the Russian translation; see C. Darwin to V. O. Kovalevsky, 16 May 1867; CCD, Vol. 15, p. 261.

94 Stebbins, 1972, p. 128, quotes that Vogt was one of the best-known Darwinians at that time in France.

95 Quatrefages, 1894, p. 158.

96 C. Darwin to C. Vogt, 30 October 1869; Genève, Bibliothèque Publique et Universitaire, Ms. fr. 2188, ff. 298-299: Charles Darwin. L.a.s. à Carl Vogt. - Down Beckenham (Kent), 30 Oct. 1869.

97 Darwin, 1868, pp. i-xvi. 
commented on the work of authors other than himself, which may have contributed to his securing a second engagement as preface writer. However, in the preface to Descent, Vogt went a step further. Although his language was absolutely respectable, this time Vogt made no secret of his strict materialism. Moreover, he held that materialism was a substantial trait of Darwinism: "There is no place, neither in the inorganic nor in the organic world, for a third power, independent of matter and capable of handling it [the matter] at its discretion and whim. This is, it appears to me, the true core of what we have agreed to call Darwinism." ${ }^{98}$ Although there were no explicit attacks on religion, such passages would not have pleased devout readers. Nevertheless, Vogt's preface was not revised in later French editions of Descent.

It is possible that Darwin might have wanted to dispense with Vogt's services, but this would have made life difficult for him, since it was thanks to Vogt that Darwin had got in touch with Moulinié in the first place. As Darwin was keen to engage Moulinié, he had little choice but to employ Vogt as well; furthermore, Reinwald, the publisher, was a good friend of the Swiss-German materialist and would not have wanted to offend Vogt, even after Barbier had taken over from Moulinié after the latter's death. Yet, even if Darwin did, to some extent, get stuck with Vogt, he certainly benefited from the association and never tried to distance himself from Vogt, who, after all, was one of the most fervent propagators of Darwinism at the time and a naturalist of considerable influence, particularly in France. Not for nothing did Darwin quote one of Vogt's eulogies for Darwinism on the first page of the preface to Descent. The necessity of having influential supporters abroad and, not least, the need for competent and sympathetic translators - hard to find at that time - prevailed over Darwin's much cited and usually cautious behaviour when it came to politics and religion. Despite being the perfect gentleman, Darwin clearly did not object to associating himself with a rogue, if a rogue was the right person to propagate his theory on selection.

\section{Acknowledgements}

We would like to thank the editors of the Darwin Correspondence Project, notably Shelley Innes and Nick Gill, who put at our disposal

\footnotetext{
98 The original wording in Darwin, 1872, xi-xii: "Il n'y a pas de place, ni dans le monde inorganique, ni dans le monde organique, pour une force tierce indépendante de la matière, et pouvant façonner celle-ci suivant son gré ou son caprice. Tel est, ce me semble, le véritable noyau de ce qu'on est convenu d'appeler le Darwinisme."
} 
some of Darwin's unpublished letters as well as the latest Volume 15 of the Correspondence edition prior to its official release. We are greatly indebted to Jim Endersby for his valuable comments on the paper and for his support of the project; we are also grateful to Adrian Desmond, Gerd Grasshoff and various anonymous referees of the Journal of the History of Biology, who drew our attention to weaknesses of an earlier draft; and finally we would like to thank Margareta Simons, who edited the paper, and Lieve and Lut Romanino, who revised some of the translations.

\section{References}

Bernbeck, Gerhard. 1977. "Carl Vogt: Bekanntes, weniger bekanntes und neues aus seinem Leben." Mitteilungen des Oberhessischen Geschichtsvereins Giessen 62: 221236.

Bowler, Peter J. 1986. Theories of Human Evolution: A Century of Debate, 1844-1944. Baltimore: Johns Hopkins University Press; Oxford: Basil Blackwell.

Bröker, Werner. 1972. Politische Motive naturwissenschaftlicher Argumentation gegen Religion und Kirche im 19. Jahrhundert, dargestellt am Materialisten Karl Vogt. Münster: Aschendorfsche Verlagsbuchhandlung.

Brooke, John H. 2003. "Darwin and Victorian Christianity." Jonathan Hodge and Gregory Radick (eds.), The Cambridge Companion to Darwin. Cambridge University Press, pp. 192-213.

Browne, Janet. 2003. Charles Darwin: The Power of Place. London: Pimlico.

Burkhardt, Frederick H. et al. (eds.). 1985-2005. The Correspondence of Charles Darwin, Vols. 1-15. Cambridge: Cambridge University Press.

Darwin, Charles. ${ }^{1} 1860,{ }^{2} 1863$. Über die Entstehung der Arten im Thier- und PflanzenReich durch natürliche Züchtung, oder Erhaltung der vervollkommneten Rassen im Kampfe um's Daseyn. Paris: Reinwald.

-1868. De la variation des animaux et des plantes sous l'action de la domestication. Paris: Reinwald.

1872. La Descendance de l'homme et la sélection sexuelle. Paris: Reinwald.

2004. The Descent of Man: Selection in Relation to Sex. London: Penguin Books.

Desmond, Adrian and Moore, James. 1992. Darwin. London: Penguin Books.

Di Gregorio, Mario (ed.). 1990. Charles Darwin's Marginalia, Vol. 1. New York/London: Garland Publishing.

Gregory, Frederick. 1977. Scientific Materialism in Nineteenth Century Germany. Dordrecht/Boston: Reidel Publishing.

Harvey, Joy. 1997. “Almost a Man of Genius”. Clémence Royer, Feminism, and Nineteenth-Century Science. New Brunswick, N.J: Rutgers University Press.

Jeanblanc, Helga. 1999. "Carl Vogt et la propagation du matérialisme scientifique en France." Jean-Claude Pont et al. (eds.), Carl Vogt: Science, Philosophie et Politique. Chêne-Bourg: Georg, pp. 177-196.

Judel, Günther Claus. 2004. "Der Liebigschüler Carl Vogt als Wissenschaftler, Philosoph und Politiker." Giessener Universitätsblätter 37: 51-56. 
Junker, Thomas. 1991. "Heinrich Georg Bronn und die Entstehung der Arten." Sudhoffs Archiv 75: 180-208.

- 1995. "Darwinismus, Materialismus und die Revolution von 1848 in Deutschland. Zur Interaktion von Politik und Wissenschaft." History and Philosophy of the Life Sciences 17: 271-302.

Junker, Thomas and Backenköhler, Dirk. 1999. "Vermittler dieses allgemeinen geistigen Handels: Charles Darwins deutsche Verleger und Übersetzer bis 1882." Armin Geus et al. (ed.), Repräsentationsformen in den biologischen Wissenschaften. Berlin: Verlag für Wissenschaft und Bildung, pp. 249-280.

Kanz, Kai Torsten. 1997. Nationalismus und internationale Zusammenarbeit in den Naturwissenschaften. Die deutsch-französischen Wissenschaftsbeziehungen zwischen Revolution und Restauration, 1789-1832. Stuttgart: Steiner.

Kockerbeck, Christoph. 1999. Carl Vogt, Jacob Moleschott, Ludwig Büchner, Ernst Haeckel: Briefwechsel. Marburg: Basilisken-Presse.

Montgomery, William M. 1972. "Germany." Thomas F. Glick (ed.), The Comparative Reception of Darwinism. Austin/London: University of Texas Press, pp. 81-115.

Pont, Jean-Claude et al. (eds.). 1998. Carl Vogt (1817-1895): science, philosophie et politique. Chêne-Bourg: Georg.

Quatrefages de Bréau, Jean-Louis Armand de. 1867. Comptes rendus des scéances de l'Académie des Sciences 64: 1-5.

1894. Les émules de Darwin. Paris: Alcan.

Richards, Evelleen. 1989. "The Moral Anatomy of Robert Knox: The Interlay between Biological and Social Thought in Victorian Scientific Naturalism." Journal of the History of Biology 22: 373-436.

Rupke, Nicolaas. 2000. "Translation Studies in the History of Science: The Example of Vestiges." The British Journal for the History of Science 33: 209-222.

— 2005. "Neither Creation nor Evolution: The Third Way in Mid-Nineteenth Century Thinking about the Origin of Species." Annals of the History and Philosophy of Biology 10: 143-172.

Sanner, Burkhard. 1994. "Carl Vogt als Naturwissenschaftler." Mitteilungen des Oberhessischen Geschichtsvereins Giessen 79: 231-292.

Stebbins, Robert E. 1972. "France." Thomas F. Glick (ed.), The Comparative Reception of Darwinism. Austin/London: University of Texas Press, pp. 117-163.

Stocking, George W. 1987. Victorian Anthropology. New York: The Free Press; London: Macmillan.

Tort, Patrick. 1996. "Karl Vogt." Dictionnaire du Darwinisme et de l'évolution, Vol. 3. Paris: Presses universitaire de France, pp. 4485-4488.

Vogt, Carl. 1845-1847. Physiologische Briefe für Gebildete aller Stände. Giessen: Ricker'sche Buchhandlung.

- 1851a. Natürliche Geschichte der Schöpfung des Weltalls, der Erde und der auf ihr befindlichen Organismen, begründet auf die durch die Wissenschaft errungenen Tatsachen. Braunschweig: Vieweg \& Sohn.

— 1851b. Untersuchungen über Thierstaaten. Frankfurt am Main: Literarische Anstalt.

- 1855. Köhlerglaube und Wissenschaft. Eine Streitschrift gegen Hofrath Rudolph

Wagner in Göttingen. Giessen: Ricker'sche Buchhandlung.

- 1859. Altes und Neues aus dem Thier- und Menschenleben. Frankfurt am Main: Literarische Anstalt. 
1863. Vorlesungen über den Menschen, seine Stellung in der Schöpfung und in der Geschichte der Erde. Giessen: Ricker'sche Buchhandlung.

1864. Lectures on Man, his Place in Creation, and in the History of the Earth. London: Longman, Green, and Roberts.

- 1867. Mémoire sur les microcéphales ou Hommes-Singes. Geneva/Basel: Librairie H. Georg.

1896. Aus meinem Leben. Stuttgart: Nägele.

Vogt, William. 1896. La vie d'un homme: Carl Vogt. Paris: Schleicher Frères; Stuttgart: Nägele.

Vucinich, Alexander. 1972. "Russia: Biological Sciences." Thomas F. Glick (ed.), The Comparative Reception of Darwinism. Austin/London: University of Texas Press, pp. 227-255.

1988. Darwin in Russian Thought. Berkeley/Los Angeles/London: University of California Press. 